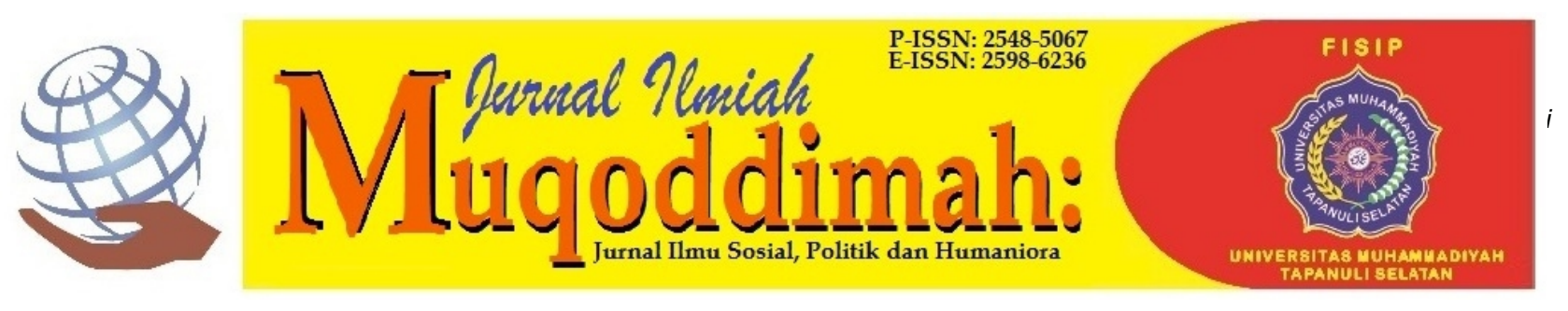

\title{
Dominasi Sekolah Negeri Terhadap Sekolah Swasta Sebagai Penyebab Kekerasan Simbolik Terhadap Siswa Sekolah Swasta
}

\author{
Suardi ${ }^{1}$, Andi Agustang ${ }^{2}$, Jumadi $^{3)}$ \\ Program Studi Pendidikan Sosiologi Universitas Muhammadiyah Makassar ${ }^{1}{ }^{1}$ \\ Jalan Sultan Alauddin 259 Makassar \\ Program Pascasarjana Universitas Negeri Makassar 2, 3) \\ Jalan Bonto Langkasa, Banta-Bantaeng, Kota Makassar, Sulawesi Selatan \\ suardi@unismuh.ac.id ${ }^{1)}$ \\ andi.agustang@unm.ac.id²) \\ jumadi@unm.ac.id ${ }^{3)}$
}

\begin{abstract}
Abstrak
Siswa sekolah swasta mendapatkan kekerasan simbolik karena adanya dominasi sekolah negeri terhadap sekolah swasta. Tujuan dari penelitian ini adalah untuk menganalisis menemukan adanya dominasi sekolah negeri terhadap sekolah swasta yang selevel dan selabel. Penelitian ini dilakukan menggunakan metode mixed method concurrent embedded di 10 sekolah swasta dan 6 sekolah negeri. Hasil penelitian menunjukkan dominasi sekolah negeri menjadi salah satu faktor penyebab kekerasan simbolik terhadap siswa sekolah swasta. Dominasi sekolah negeri terhadap sekolah swasta terbagi menjadi beberapa varian yaitu (a) Dominasi kelas dominan terhadap kelas popular dan kelas borjuasi yang selevel, (b) Dominasi kelas dominan terhadap kelas popular dan kelas borjuasi yang tidak selevel, (c) Dominasi kelas dominan terhadap kelas populer dan kelas borjuasi yang selabel dan (c) Dominasi kelas dominan terhadap kelas populer dan kelas borjuasi yang tidak selabel.
\end{abstract}

Kata kunci: Dominasi, Kekerasan, Simbolik

\begin{abstract}
Private school students get symbolic violence because of the dominance of public schools over private schools. The purpose of this study is to analyze finding the dominance of public schools over private schools of the same level and label. This research was conducted using the mixed method concurrent embedded method in 10 private schools and 6 public schools. The results showed that the dominance of public schools was one of the factors causing symbolic violence against private school students. The dominance of public schools over private schools is divided into several variants, namely (a) the dominance of the dominant class over the popular class and the bourgeois class that is at the same level, (b) the dominance of the dominant class over the popular class and the bourgeois class that is not on the same level, (c) the dominance of the dominant class over the class the popular and the labeled bourgeoisie and (c) the dominance of the dominant class over the popular class and the unlabeled bourgeoisie.
\end{abstract}

Keywords: Domination, Symbolic, Violence

\section{PENDAHULUAN}

Konsep kekerasan simbolik oleh (Bourdieu, 1993) digunakan untuk menganalisis mekanisme penguasaan kelas dominan terhadap kelas borjuasi kecil dan kelas populer untuk melakukan pemaksaan ideologi dan pemaksaan habitus. Mekanisme kekerasan simbolik dilakukan karena kuasa yang dimiliki oleh kelas dominan dalam suatu praktik sosial antara 
JURNAL ILMIAH MUQODDIMAH: Jurnal IImu Sosial, Politik Dan Humaniora E-ISSN : 2598-6236

http://jurnal.um-tapsel.ac.id/index.php/muqoddimah
Dominasi Sekolah Negeri Terhadap Sekolah Swasta Sebagai Penyebab Kekerasan Simbolik Terhadap Siswa Sekolah Swasta. (Suardi, Andi Agustang, Jumadi)

sekolah swasta dan sekolah negeri di Kecamatan Bissappu Kabupaten Bantaeng. Hal tersebut berdasarkan hasil observasi, dokumentasi dan wawancara awal peneliti tahun 2018, di masyarakat Kecamatan Bissappu Kabupaten Bantaeng, peneliti melihat berbagai fenomenafenomena sosial yang mengindikasikan embrio kekerasan simbolik karena adanya dominasi sekolah negeri sebagai kelas dominan kepada siswa sekolah swasta karena sekolah swasta hanya kelas borjuasi kecil dan bahkan kelas populer.

Stratifikasi sosial yang terjadi dalam masyarakat dalam sistem pendidikan yang membagi sekolah Swasta dan Negeri merupakan faktor pembentuk kelas sosial (dominan, borjuasi kecil, populer), menempatkan sekolah Negeri sebagai kelas dominan dan sekolah swasta sebagai kelas borjuasi kecil dan populer. Kelas yang berbeda menimbulkan habitus yang berbeda antara sekolah Negeri dengan sekolah Swasta, sehingga melakukan pemaksaan ideologi dan melakukan pemaksaan habitus, agar sekolah swasta mengikuti habitus sekolah Negeri.

Mekanisme pemaksaan habitus kelas dominan (sekolah negeri) terhadap kelas borjuasi kecil dan populer secara tidak disadari oleh kelas yang borjuasi kecil dan populer. Dengan kata lain, sekolah swasta dari kelas bawah dipaksa untuk mengikuti atau layaknya kelas dominan (sekolah Negeri). Untuk menganalisis dominasi sekolah negeri sebagai kelas dominan terhadap kelas borjuasi kecil dan populer dalam kekerasan simbolik terhadap siswa sekolah swasta teori yang dijadikan sebagai pisau analisis untuk membedah tema tersebut adalah teori (Bourdieu, 1993) tentang kelas sosial yang terbagi menjadi kelas dominan, kelas borjuasi kecil dan kelas populer.

Berbagai penelitian menunjukkan bahwa dunia Pendidikan tidak terlepas dari kekerasan simbolik karena adanya perbedaan kelas seperti penelitian (Suardi, Agustang, \& Jumadi, 2020b) tentang kekerasan simbolik terhadap siswa dalam kontestasi wacana melalui frame stereotip terhadap siswa sekolah swasta, menemukan salah satu faktor penyebab kekerasan simbolik karena adanya perbedaan kelas sosial. Penelitian yang lain adalah (Suardi, Agustang, \& Jumadi, 2020a) kekerasan simbolik terhadap siswa dalam kontestasi wacana melalui frame stereotip terhadap mahasiswa juga menemukan menemukan salah satu faktor penyebab kekerasan simbolik karena adanya perbedaan kelas sosial, sehingga kelas sosial merupakan aspek penting dalam melakukan kekerasan simbolik, dan penelitian (Laksana, 2012) pelanggengan kekuasaan dengan menggunakan kelas sosial. Stigma atau stereotip merupakan perilaku yang diskriminatif (Arifin \& Suardi, 2017), masalah sosial yang harus diatasi (Nursalam \& Suardi, 2016), dan penyimpangan sosial yang tidak sesuai dengan nilai dan norma sosial masyarakat (Suardi, 2018). Berbagai penelitian sebelumnya belum menjelaskan secara komprehensif bagaimana dominasi sekolah negeri terhadap kelas borjuasi kecil dan kelas populer yang selevel, tidak selevel, selabel dan tidak selabel, sehingga penelitian ini merupakan penelitian yang menghasilkan temuan bersifat "orisinal".

Berbagai upaya yang telah dilakukan sekolah swasta untuk menjadi kelas dominan seperti penguatan karakter melalui model kolaborasi sosial (Suardi, Agustang, \& Sahabuddin, 2020), karena pendidikan karakter di Kabupaten Bantaeng menjadi isu hangat di kalangan orang tua (Suardi, Agustang, \& Jumadi, 2020b), berbagai sekolah swasta menerapkan pendidikan moral, akhlak dan karakter peserta didik, karena pendidikan karakter bisa diterapkan disemua jenjang pendidikan mulai jenjang pendidikan dasar (Nursalam et al., 2020), (Kanji et al., 2019b), (Kanji et al., 2020), (Kanji et al., 2019a), jenjang sekolah menengah (Suardi et al., 2018), (Suardi et al., 2019), dan jenjang pendidikan tinggi (Suardi, Nursalam, \& Kanji, 2020) (Suardi \& Syarifuddin, 2018), namun belum menempatkan sekolah swasta sebagai kelas dominan.

Hal tersebut penting diteliti karena penelitian ini akan memberikan kontribusi terhadap penelitian yang telah ada dalam domain kelas sosial yang terbagi menjadi kelas dominan, borjuasi kecil dan kelas populer yang selevel, tidak selevel, selabel dan tidak selabel. Ada beberapa faktor yang menjadi dasar penelitian (research basic) yaitu (1) latar belakang sosial yaitu perubahan masyarakat yang lebih fanatik terhadap sekolah negeri sebagai kelas dominan dan diskriminatif terhadap sekolah swasta sebagai kelas borjuasi kecil dan kelas populer. (2) 
JURNAL ILMIAH MUQODDIMAH: Jurnal IImu Sosial, Politik Dan Humaniora E-ISSN : 2598-6236

http://jurnal.um-tapsel.ac.id/index.php/muqoddimah
Dominasi Sekolah Negeri Terhadap Sekolah Swasta Sebagai Penyebab Kekerasan Simbolik Terhadap Siswa Sekolah Swasta. (Suardi, Andi Agustang, Jumadi)

Latar belakang intelektual yaitu konstruksi gerakan perubahan menuju kesetaraan kelas antara sekolah swasta dengan sekolah Negeri melalui misi perubahan dan pemberdayaan menuju egaliter. (3) Latar belakang penelitian yaitu kekosongan teori Pierre Bourdieu dalam melihat kekerasan simbolik oleh kelas dominan terhadap kelas borjuasi kecil dan kelas populer yang selevel, tidak selevel, selabel dan tidak selabel.

Penelitian ini menggunakan filosofi research dalam upaya pengembangan ilmu pengetahuan sebagai basis penelitian (Agustang, A. 2011), maka penelitian memiliki basis ontologi sosiologi dan metodologi, epistemologi sosiologi dan metodologi dan aksiologi sosiologi dan metodologi, yaitu (1) Ontologi Penelitian: (a) Ontologi sosiologi, basis penelitian menggunakan paradigma kritis yang memandang realitas adalah bentukan sejarah yang penuh dengan pembelokan dan hegemoni . Melihat realitas kekerasan simbolik terhadap siswa sekolah swasta sebagai suatu realitas sosial bentukan sejarah yang sejak dulu masyarakat fanatik dengan sekolah negeri sebagai kelas dominan dan diskriminatif terhadap sekolah swasta sebagai kelas borjuasi kecil dan kelas populer, padahal sekolah swasta juga memberikan kontribusi bagi masyarakat dalam dunia pendidikan sama seperti sekolah negeri. Sekolah swasta sebagai entitas yang selalu terdominasi dan terhegemoni oleh sekolah negeri sebagai kelas dominan untuk mengikuti praktik pendidikan terbaik sekolah negeri. Oleh karena itu dalam mengkaji realitas peneliti menggunakan konsep kekerasan simbolik dan kelas sosial. (b) Ontologi metodologi peneliti melihat realitas dari sudut pandang mikro/ subjek/ aktor dan sudut pandang makro/ struktur/ objek. (2) Epistemologi Penelitian: (a) Epistemologi sosiologi menggunakan paradigma kritis (prakxis: analisis dan aksi), sehingga dalam penelitian peneliti menggunakan (1) dialektika wacana untuk membongkar hegemoni sekolah negeri sebagai kelas dominan terhadap sekolah swasta sebagai kelas borjuasi kecil dan kelas populer, agar sekolah swasta mengalami perubahan menuju kesetaraan kelas antara sekolah swasta dan sekolah negeri di masyarakat tanpa adanya dominasi dan diskriminasi melalui proses pemberdayaan yang dilakukan untuk sekolah swasta dengan misi perubahan. (b) Epistemologi metodologi menggunakan paradigma mixed method (kualitatif-kuantitatif) dengan model mixed methods concurrent embedded, karena peneliti hanya menggunakan data kuantitatif sebagai data pelengkap dari data kualitatif, sehingga dalam penelitian ini tahap pertama menggunakan metode penelitian kualitatif dan tahap kedua menggunakan metode penelitian kuantitatif untuk menafsir kualitatif ke kuantitatif secara bersama-sama namun dengan bobot yang berbeda. (3) Aksiologi Penelitian: (a) Aksiologi Sosiologi berusaha menemukan teori substantif kelas dominan terhadap kelas borjuasi kecil dan kelas populer yang selevel, tidak selevel, selabel dan tidak selabel. (b) Aksiologi Metodologi yaitu (1) Melakukan kritik terhadap kekerasan yang dilakukan oleh aktor-aktor sekolah negeri terhadap siswa sekolah swasta karena perbedaan kelas sosial. (2) Pembongkaran terhadap pembelokan sejarah sekolah swasta sebagai sekolah yang memiliki kontribusi kepada masyarakat sejak dulu bersama sekolah negeri dan memberikan kontribusi kepada masyarakat dalam menciptakan generasi yang berakhlak di Kecamatan Bissappu Kabupaten Bantaeng, (3) Non Free Value. Peneliti melakukan penelitian tidak bebas nilai, namun terikat dengan nilai sekolah swasta dan memihak kepada siswa dan sekolah swasta yang mengalami kekerasan simbolik. (4) Transformatif. Peneliti berupaya untuk mengkonstruksi kesetaraan antara siswa sekolah swasta dan siswa sekolah negeri, antara sekolah negeri dan sekolah swasta menjadi egaliter.

Berdasarkan filosofi research maka problem statement penelitian ini adalah (1) secara ontologi sosiologis realitas dilihat menggunakan paradigma kritis yaitu realitas sebagai bentukan sejarah yang penuh hegemoni dan pembelokan, sehingga konsep sosiologi yang digunakan adalah kekerasan simbolik dan kelas sosial. Sedangkan ontologi metodologis realitas dilihat dari sudut pandang mikro-makro, struktur-aktor dan subjek-objek, (2) secara epistemologi sosiologis dilakukan dengan pendekatan prakxis yaitu analisis dan aksi, sehingga dalam peneliti melakukan dialektika wacana, sedangkan epistemologi metodologis menggunakan mix method concurrent embedded yaitu gabungan kualitatif dan kuantitatif dengan data kualitatif yang lebih dominan dan 
JURNAL ILMIAH MUQODDIMAH: Jurnal IImu Sosial, Politik Dan Humaniora E-ISSN : 2598-6236

http://jurnal.um-tapsel.ac.id/index.php/muqoddimah
Dominasi Sekolah Negeri Terhadap Sekolah Swasta Sebagai Penyebab Kekerasan Simbolik Terhadap Siswa Sekolah Swasta. (Suardi, Andi Agustang, Jumadi)

kuantitatif hanya pelengkap, (3) secara aksiologi sosiologis berupaya menemukan kekerasan simbolik kelas dominan terhadap kelas borjuasi kecil dan kelas populer yang selevel, tidak selevel, selabel dan tidak selabel, sedangkan aksiologi metodologis, peneliti melakukan kritik, melakukan pembongkaran wacana, non free value dan melakukan transformatif. Atas dasar tersebut peneliti tertarik untuk melakukan penelitian tentang "Dominasi Sekolah Negeri Sebagai Kelas Dominan Terhadap Kelas Borjuasi Kecil Dan Populer Dalam Kekerasan Simbolik Terhadap Siswa Sekolah Swasta Kabupaten Bantaeng".

\section{METODE}

Penelitian ini menggunakan metode penelitian campuran (mixed methods). Model mixed methods concurrent embedded (Creswell, 2017), merupakan gabungan paradigma positivistik dan post positivistik (Nursalam et al., 2016), Dalam penelitian ini tahap pertama menggunakan metode penelitian kualitatif dan tahap kedua menggunakan metode penelitian kuantitatif secara simultan atau Bersama-sama namun dengan bobot yang berbeda. Tempat penelitian atau lokasi penelitian secara umum di Kecamatan Bissappu Kabupaten Bantaeng, yang memiliki 6 sekolah swasta dan 6 sekolah negeri..

Teknik pengumpulan data yang digunakan adalah penyebaran angket model tertutup, observasi langsung, wawancara terpimpin, catatan lapangan dan dokumentasi. Analisis data kualitatif dilakukan melalui tahapan reduksi data, display data dan penarikan kesimpulan, sedangkan data analisis data kuantitatif menggunakan verifikasi kuesioner, tabulasi data kuesioner dan persentase data kuesioner. Keabsahan data kualitatif menggunakan triangulasi sumber, triangulasi waktu dan triangulasi metode, sedangkan data kuantitatif melalui uji reliabilitas (ketepatan) dan uji validasi (benar) (Creswell, 2017).

\section{HASIL DAN PEMBAHASAN}

Di kecamatan Bissappu Kabupaten Bantaeng terdapat berbagai tipe dominasi, secara umum yaitu (a) tipe dominasi kelas dominan sekolah negeri terhadap sekolah negeri yang lain, (b) tipe dominasi kelas dominan sekolah negeri terhadap sekolah swasta, (c) tipe kelas dominan sekolah swasta terhadap sekolah negeri, (d) tipe kelas dominan sekolah swasta terhadap sekolah swasta yang lain. Namun diantara semua tipe dominasi yang ditemukan tipe dominasi kelas dominan sekolah negeri terhadap sekolah swasta yang paling banyak di masyarakat. Data hasil wawancara yang dilakukan dengan 43 informan terdiri dari pemerintah, siswa, guru, kepala sekolah, alumni baik sekolah swasta maupun sekolah negeri, diperoleh data sekolah negeri sebagai sekolah unggul seperti SMA 1 Bantaeng dan SMA 2 Bantaeng, sama-sama unggul namun lebih unggul SMA 1 Bantaeng. Sekolah yang terbaik adalah SMA 1 Bantaeng menurut pandangan orang sejak dulu. SMA 1 Bantaeng adalah sekolah terbaik, unggul dan favorit di Kabupaten Bantaeng. Sekolah yang paling bagus SMA 1 Bantaeng untuk kecamatan Bissappu dan Kabupaten Bantaeng. Level dibawahnya SMA 1 Bantaeng adalah SMA 2 Bantaeng. SMA 1 Bantaeng adalah sekolah pertama dan sudah terkenal sejak dahulu sebagai "sekolah terbaik. SMA 1 Bantaeng dengan kualitas standar Pendidikan nasional yang terbaik di Kabupaten Bantaeng, sehingga sekolah SMA 1 Bantaeng untuk terus menjadi yang terbaik di antara sekolah yang lain baik swasta maupun negeri. Sedangkan untuk jenjang sekolah menengah pertama yang paling bagus adalah SMP 1 Bissappu yang memiliki kualitas pembelajaran yang lebih bagus, selain itu standar lulusan kedua sekolah tersebut ketika masuk pada tingkatan sekolah menengah atas memiliki kualitas yang baik Untuk sekolah negeri jenjang sekolah menengah pertama dilihat dari segi akreditasi maka SMP 1 Bissappu yang paling bagus. Sedangkan sekolah swasta yang terbaik dna paling bagus di Kecamatan Bissappu adalah MA Muhammadiyah Panaikang memiliki kelebihan dalam IMTAQ sehingga terkenal dengan sekolah berbasis agamanya.

Data hasil observasi peneliti pada sekolah negeri dan sekolah swasta di Kecamatan Bissappu, diperoleh data sekolah sebagai kelas domina diantara semua sekolah yang ada di 
JURNAL ILMIAH MUQODDIMAH: Jurnal Ilmu Sosial, Politik Dan Humaniora E-ISSN : 2598-6236

http://jurnal.um-tapsel.ac.id/index.php/muqoddimah
Dominasi Sekolah Negeri Terhadap Sekolah Swasta Sebagai Penyebab Kekerasan Simbolik Terhadap Siswa Sekolah Swasta. (Suardi, Andi Agustang, Jumadi)

Kecamatan Bissappu baik jenjang sekolah menengah pertama dan sekolah menengah atas, baik sekolah negeri maupun sekolah swasta, baik sekolah dibawah pengelolaan kementerian pendidikan maupun dibawah pengelolaan kementerian agama yaitu Sekolah Menengah Atas (SMA) 1 Bantaeng, mendominasi semua sekolah di Kecamatan Bissappu baik sekolah negeri SMA 2 Bantaeng maupun sekolah swasta Madrasah Aliyah (MA) Muhammadiyah Panaikang dan Madrasah Aliyah (MA) Ma'arif Panaikang dan MA Ma'arif Campagaloe, sekolah Menengah Kejuruan Swasta (SMKS) Darul Ulum Panaikang. Sedangkan untuk sekolah menengah pertama sekolah sebagai kelas dominan di antara sekolah menengah pertama yang ada di Kecamatan Bissappu baik negeri yang lain, sekolah swasta, baik sekolah dibawah pengelolaan kementerian pendidikan maupun dibawah pengelolaan kementerian agama yaitu Madrasah Tsanawiyah (MTs) Muhammadiyah Panaikang, Sekolah Menengah Pertama (SMP) Swasta Ponpes Darul Ulum, Madrasah Tsanawiyah (MTs) Ma'arif Panaikang, Sekolah Menengah Pertama (SMP) Persatuan Guru Republik Indonesia (PGRI) Campagaloe, Sekolah menengah Pertama (SMP) IT Al-Ihsan Wahdah Islamiyah, Sekolah menengah Pertama (SMP) Negeri 3 Bissappu, Sekolah menengah Pertama (SMP) Negeri 3 Bissappu dan Sekolah menengah Pertama (SMP) Negeri 4 Bissappu. Untuk sekolah swasta dengan sekolah swasta yang lain, sekolah yang paling dominan adalah Madrasah Aliyah (MA) Muhammadiyah Panaikang terhadap sekolah swasta yang lain baik jenjang sekolah menengah pertama (SMP) atau Madrasah Tsanawiyah yaitu Madrasah Aliyah (MA) Ma'arif Panaikang dan MA Ma'arif Campagaloe, sekolah Menengah Kejuruan Swasta (SMKS) Darul Ulum Panaikang, Madrasah Tsanawiyah (MTs) Muhammadiyah Panaikang, Sekolah Menengah Pertama (SMP) Swasta Ponpes Darul Ulum, Madrasah Tsanawiyah (MTs) Ma'arif Panaikang, Sekolah Menengah Pertama (SMP) Persatuan Guru Republik Indonesia (PGRI) Campagaloe, Sekolah menengah Pertama (SMP) IT Al-Ihsan Wahdah Islamiyah dan Sekolah Menengah Pertama (SMP) 4 Bissappu.

Sekolah negeri secara umum sebagai kelas dominan dalam pertarungan dengan sekolah swasta pada suatu arena (feil) pendidikan di Kecamatan Bissappu untuk melakukan pemaksaan habitus yaitu dengan menjadikan sekolah negeri sebagai contoh dalam menciptakan kebiasaan belajar yang bagus dan pengelolaan praktik pendidikan yang terbaik. Dominasi yang terjadi terdiri dari empat tipe yaitu berdasarkan dominasi kualitas dan dominasi kuantitas.

a. Tipe dominasi kelas dominan sekolah menengah atas negeri terhadap sekolah negeri setingkat yang lain menjadikan sekolah menengah atas (SMA) 1 Bantaeng sebagai kelas dominan terhadap sekolah negeri setingkat. Hal tersebut Berdasarkan hasil angket dengan 301 informan yaitu:

Diagram 1.

Dominasi sekolah menengah atas (SMA) 1 Bantaeng sebagai kelas dominan

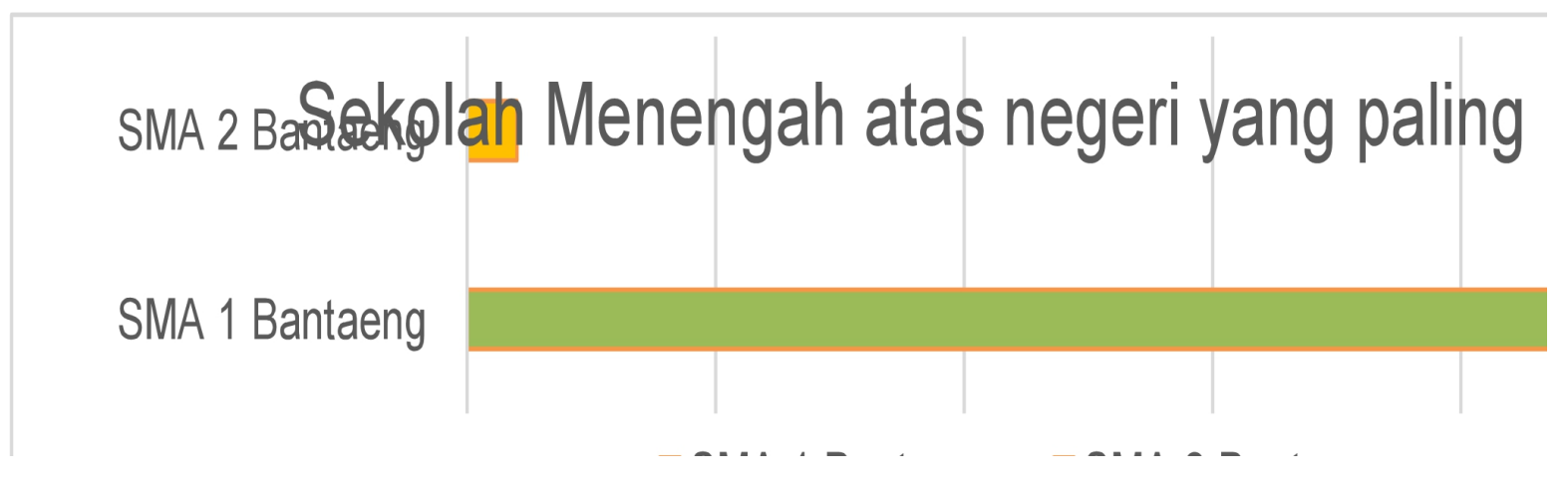


JURNAL ILMIAH MUQODDIMAH:

Jurnal Ilmu Sosial, Politik Dan Humaniora

E-ISSN : 2598-6236

http://jurnal.um-tapsel.ac.id/index.php/muqoddimah
Dominasi Sekolah Negeri Terhadap Sekolah Swasta Sebagai Penyebab Kekerasan Simbolik Terhadap Siswa Sekolah Swasta. (Suardi, Andi Agustang, Jumadi)

Hasil angket dari 301 responden terkait keunggulan sekolah menengah atas negeri terhadap sekolah menengah atas negeri yang setingkat, ada 289 responden atau $96.01 \%$ dari 301 responden yang mengatakan sekolah menengah atas (SMA) 1 Bantaeng lebih unggul dibandingkan sekolah menengah atas (SMA) 2 Bantaeng dan ada 12 orang responden atau $3.99 \%$ dari dari 301 responden yang memilih sekolah menengah atas (SMA) 2 Bantaeng lebih unggul dibandingkan sekolah menengah atas (SMA) 2 Bantaeng. Tipe dominasi sekolah menengah atas negeri terhadap sekolah negeri yang lain yang selevel yaitu:

Tabel 1.

Kategori Dominasi sekolah menengah atas (SMA) 1 Bantaeng sebagai kelas dominan

\begin{tabular}{ccccc}
\hline No & $\begin{array}{c}\text { Interval } \\
\text { respon }\end{array}$ & Kategori & $\begin{array}{c}\text { SMA 1 } \\
\text { Bantaeng }\end{array}$ & $\begin{array}{c}\text { SMA 2 } \\
\text { Bantaeng }\end{array}$ \\
1 & $81-100$ & Sangat unggul & 96.01 & - \\
2 & $61-80$ & Unggul & - & - \\
3 & $41-60$ & Sedang-Sedang & - & - \\
4 & $21-40$ & Kurang Unggul & - & - \\
5 & $0-20$ & Tidak Unggul & - & 3.99 \\
\hline
\end{tabular}

Berdasarkan tabel tersebut maka dominasi sekolah SMA 1 Bantaeng g masuk kategori sangat unggul jika dibandingkan dengan SMA 2 Bantaeng, berbeda dengan dominasi sekolah SMA 2 Bantaeng yang hanya masuk kategori tidak unggul jika dibandingkan dengan SMA 1 Bantaeng.

b. Tipe kelas dominan sekolah menengah atas atau sederajat swasta terhadap sekolah swasta yang lain setingkat menjadikan sekolah MA Muhammadiyah Panaikang sebagai kelas dominan terhadap sekolah swasta setingkat. Hal tersebut Berdasarkan hasil angket dengan 301 informan yaitu:

Diagram 2.

Dominasi sekolah menengah atas MA Muhammadiyah Panaikang sebagai kelas dominan

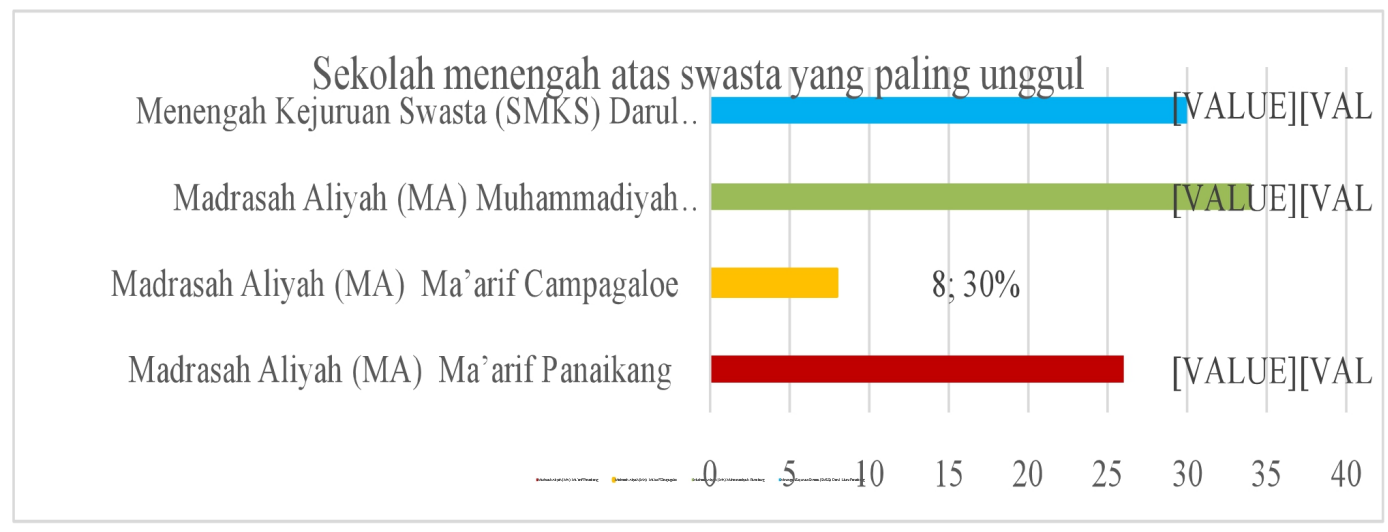

Hasil angket dari 301 responden terkait keunggulan sekolah menengah atas swasta terhadap sekolah menengah atas swasta yang setingkat, ada 105 responden atau $34.88 \%$ dari 301 responden yang memilih Madrasah Aliyah (MA) Muhammadiyah Panaikang lebih unggul dibandingkan sekolah swasta yang lain seperti Madrasah Aliyah (MA) Ma'arif Panaikang yang hanya 79 responden atau $26.24 \%$, Madrasah Aliyah (MA) Ma'arif campagaloe yang hanya 25 responden atau $8.30 \%$, Sekolah menengah kejuruan Sekolah Menengah Kejuruan Swasta 
Darul Ulum Panaikang 92 responden atau $30.56 \%$. Tipe dominasi sekolah menengah atas swasta terhadap sekolah negeri yang lain yang selevel yaitu:

Tabel 2.

Kategori Dominasi sekolah menengah atas MA Muhammadiyah Panaikang sebagai kelas dominan

\begin{tabular}{|c|c|c|c|c|c|c|}
\hline No & $\begin{array}{l}\text { Interval } \\
\text { respon }\end{array}$ & Kategori & $\begin{array}{l}\text { SMK } \\
\text { Darul } \\
\text { Ulum }\end{array}$ & $\begin{array}{c}\text { MA } \\
\text { Muhamma } \\
\text { diyah } \\
\text { Panaikang }\end{array}$ & $\begin{array}{l}\text { MA Ma'arif } \\
\text { panaikang }\end{array}$ & $\begin{array}{l}\text { MA Ma'arif } \\
\text { Campagaloe }\end{array}$ \\
\hline 1 & $81-100$ & Sangat unggul & - & - & - & - \\
\hline 2 & $61-80$ & Ünggul & - & - & - & - \\
\hline 3 & $41-60$ & $\begin{array}{l}\text { Sedang- } \\
\text { Sedang }\end{array}$ & - & - & - & - \\
\hline 4 & $21-40$ & Kurang Unggul & 30.56 & 34.88 & 26.24 & - \\
\hline 5 & $0-20$ & Tidak Unggul & - & - & - & 8.30 \\
\hline
\end{tabular}

Berdasarkan tabel tersebut maka dominasi sekolah swasta Madrasah Aliyah (MA) Muhammadiyah Panaikang memiliki nilai tertinggi meskipun masih berada kategori kurang unggul bersama dengan SMK Darul Ulum Panaikang dan MA Ma'arif panaikang, berbeda dengan dominasi Madrasah Aliyah (MA) Ma'arif Campagaloe yang hanya masuk kategori tidak unggul jika dibandingkan dengan Madrasah Aliyah (MA) Muhammadiyah Panaikang, Madrasah Aliyah (MA) Ma'arif Panaikang dan Sekolah Menengah Kejuruan Swasta Darul Ulum Panaikang.

c. Tipe dominasi kelas dominan sekolah menengah pertama negeri terhadap sekolah negeri setingkat yang lain menjadikan sekolah menengah pertama SMP 1 Bissappu sebagai kelas dominan terhadap sekolah swasta setingkat. Hal tersebut Berdasarkan hasil angket dengan 301 informan yaitu:

Diagram 3.

Dominasi sekolah menengah pertama SMP 1 Bissappu sebagai kelas dominan

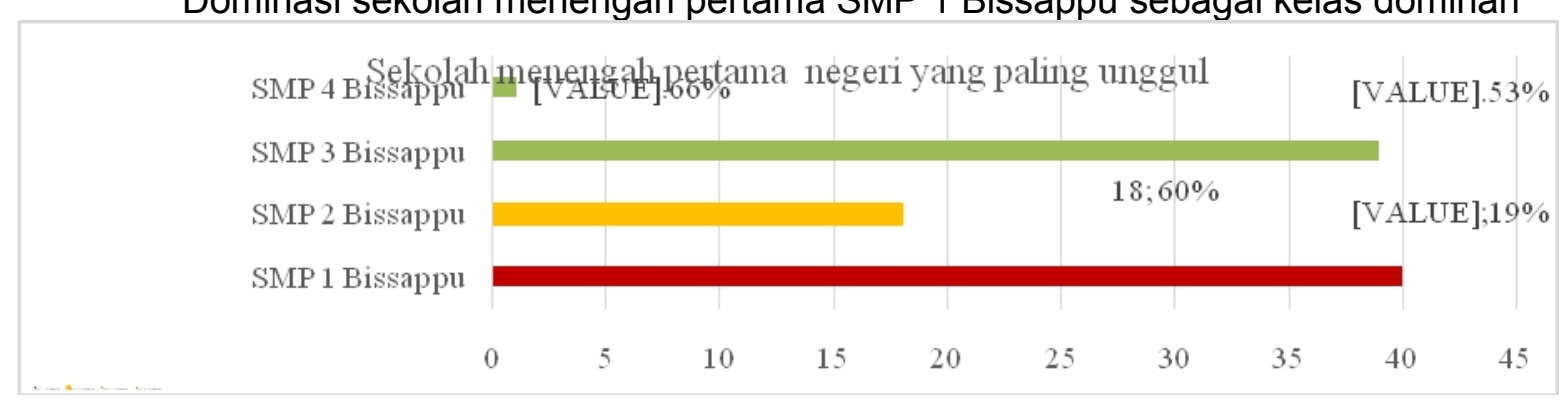

Hasil angket dari 301 responden terkait keunggulan sekolah menengah pertama negeri terhadap sekolah menengah pertama negeri yang setingkat, ada 121 responden atau $40.19 \%$ yang memilih SMP 1 Bissappu lebih unggul dibandingkan sekolah menengah pertama yang lain seperti SMP 2 Bissappu 56 responden atau $18.60 \%$, SMP 3 Bissappu 119 responden atau $39.53 \%$, dan SMP 4 Bissappu yang hanya 5 responden atau $1.66 \%$. Tipe dominasi sekolah menengah pertama negeri terhadap sekolah negeri yang lain yang selevel yaitu: 
JURNAL ILMIAH MUQODDIMAH: Jurnal IImu Sosial, Politik Dan Humaniora E-ISSN : 2598-6236

http://jurnal.um-tapsel.ac.id/index.php/muqoddimah
Dominasi Sekolah Negeri Terhadap Sekolah Swasta Sebagai Penyebab Kekerasan Simbolik Terhadap Siswa Sekolah Swasta. (Suardi, Andi Agustang, Jumadi)

Tabel 3.

Kategori dominasi sekolah menengah pertama SMP 1 Bissappu sebagai kelas dominan

\begin{tabular}{ccccccc} 
No & Interval & Kategori & SMP 1 & SMP 2 & SMP 3 & SMP 4 \\
& respon & Bissappu & Bissappu & Bissappu & Bissappu \\
1 & $81-100$ & Sangat & - & - & - & - \\
2 & $61-80$ & $\begin{array}{c}\text { unggul } \\
\text { Unggul }\end{array}$ & - & - & - & - \\
3 & $41-60$ & $\begin{array}{c}\text { Sedang- } \\
\text { Sedang }\end{array}$ & - & - & - & - \\
4 & $21-40$ & $\begin{array}{c}\text { Kurang } \\
\text { Unggul }\end{array}$ & 40.19 & - & 39.53 & - \\
5 & $0-20$ & $\begin{array}{c}\text { Tidak Unggul } \\
\text { Tidak }\end{array}$ & - & 18.60 & - & 1.66 \\
\hline
\end{tabular}

Berdasarkan tabel tersebut maka dominasi sekolah menengah pertama negeri didominasi oleh SMP 1 Bissappu memiliki nilai tertinggi meskipun masih berada pada kategori kurang unggul bersama dengan SMP 3 Bissappu, berbeda dengan dominasi SMP 2 Bissappu dan SMP 4 Bissappu yang hanya masuk kategori tidak unggul jika dibandingkan dengan SMP 1 Bissapu dan SMP 3 Bissapu.

d. Tipe kelas dominan sekolah sekolah menengah pertama atau sederajat swasta terhadap sekolah swasta yang lain setingkat menjadikan sekolah MTs Muhammadiyah Panaikang sebagai kelas dominan terhadap sekolah swasta setingkat. Hal tersebut Berdasarkan hasil angket dengan 301 informan yaitu:

Diagram 4.

Dominasi MTs Muhammadiyah Panaikang sebagai kelas dominan

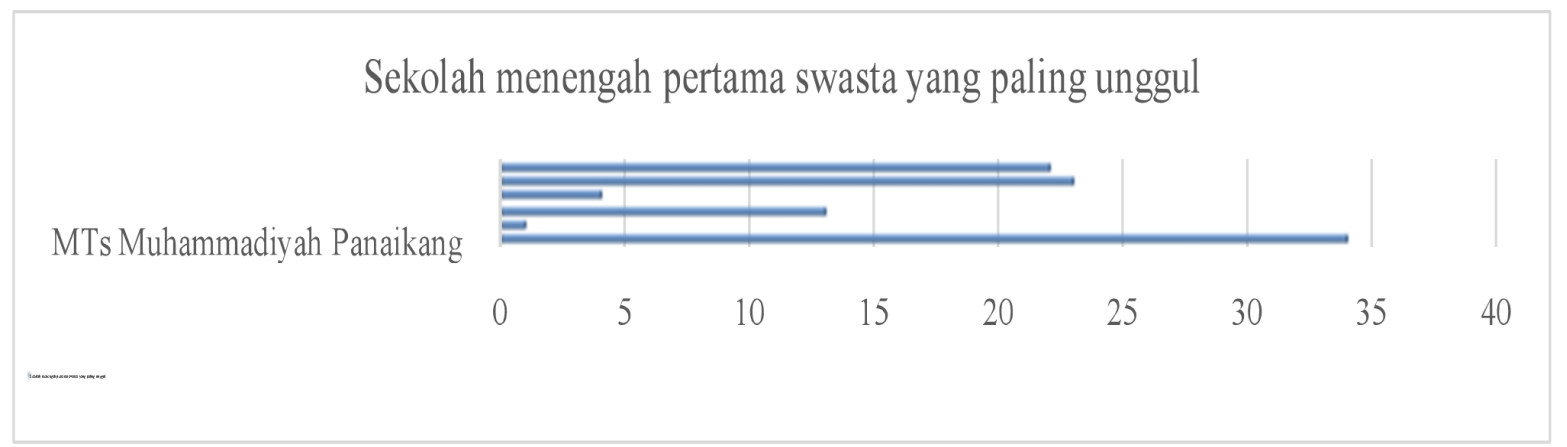

Hasil angket dari 301 responden terkait keunggulan sekolah menengah pertama atau sederajat swasta terhadap sekolah menengah pertama swasta atau sederajat yang setingkat, ada 104 responden atau 34.55 \% yang memilih Madrasah Tsanawiyah (MTs) Muhammadiyah Panaikang unggul dibandingkan sekolah menengah pertama yang lain seperti Madrasah Tsanawiyah (MTs) Raudhatus Shalihin 4 responden atau $1.32 \%$, sekolah menengah pertama (SMP) IT Al-Ihsan Wahdah Islamiyah 40 responden atau $13.28 \%$, Sekolah Menengah Pertama (SMP) Persatuan Guru Republik Indonesia Campagaloe 13 responden atau $4.31 \%$, Sekolah Menengah Pertama (SMP) swasta Ponpes Darul Ulum 71 responden atau $23.58 \%$, dan Madrasah Tsanawiyah (MTs) Ma'arif Panaikang 69 responden atau $22.92 \%$. Tipe dominasi sekolah menengah pertama swasta terhadap sekolah swasta yang lain yang selevel yaitu: 
JURNAL ILMIAH MUQODDIMAH: Jurnal IImu Sosial, Politik Dan Humaniora E-ISSN : 2598-6236

http://jurnal.um-tapsel.ac.id/index.php/muqoddimah
Dominasi Sekolah Negeri Terhadap Sekolah Swasta Sebagai Penyebab Kekerasan Simbolik Terhadap Siswa Sekolah Swasta. (Suardi, Andi Agustang, Jumadi)

Tabel 4.

Kategori dominasi sekolah menengah pertama MTs Muhammadiyah Panaikang sebagai kelas dominan

\begin{tabular}{ccccccccc} 
No & $\begin{array}{c}\text { Interval } \\
\text { respon }\end{array}$ & Kategori & A & B & C & D & E & F \\
1 & $81-100$ & Sangat unggul & - & - & - & - & - & - \\
2 & $61-80$ & Unggul & - & - & - & - & - & - \\
3 & $41-60$ & $\begin{array}{c}\text { Sedang- } \\
\text { Sedang }\end{array}$ & - & - & - & - & - & - \\
4 & $21-40$ & Kurang Unggul & 34.5 & - & - & - & 23.5 & 22.9 \\
& & & 5 & & & & 8 & 2 \\
5 & $0-20$ & Tidak Unggul & - & 1.32 & 13.2 & 4.31 & - & - \\
\hline
\end{tabular}

Keterangan:

A : Madrasah Tsanawiyah (MTs) Muhammadiyah Panaikang

B : Madrasah Tsanawiyah (MTs) Roadatussahalihin

C : Sekolah menengah pertama (SMP) IT Al-Ihsan Wahdah Islamiyah

D : Sekolah Menengah Pertama (SMP) Persatuan Guru Republik Indonesia

Campagaloe

E : Sekolah Menengah Pertama (SMP) swasta Ponpes Darul Ulum

F : Madrasah Tsanawiyah (MTs) Ma'arif Panaikang

Berdasarkan tabel tersebut maka dominasi sekolah menengah pertama swasta didominasi oleh Madrasah Tsanawiyah (MTs) Muhammadiyah Panaikang memiliki nilai tertinggi meskipun masih berada pada kategori kurang unggul bersama dengan Sekolah Menengah Pertama (SMP) swasta Ponpes Darul Ulum dan Madrasah Tsanawiyah (MTs) Ma'arif Panaikang, berbeda dengan dominasi Madrasah Tsanawiyah (MTs) Roadatussahalihin, Sekolah menengah pertama (SMP) IT Al-Ihsan Wahdah Islamiyah dan Sekolah Menengah Pertama (SMP) Persatuan Guru Republik Indonesia Campagaloe yang hanya masuk kategori tidak unggul jika dibandingkan dengan Madrasah Tsanawiyah (MTs) Muhammadiyah Panaikang, Sekolah Menengah Pertama (SMP) swasta Ponpes Darul Ulum dan Madrasah Tsanawiyah (MTs) Ma'arif Panaikang.

e. Tipe dominasi kelas dominan sekolah negeri terhadap semua sekolah swasta dan sekolah negeri yang lain menjadikan sekolah menengah atas (SMA) 1 Bantaeng sebagai kelas dominan terhadap semua sekolah swasta dan negeri baik setingkat maupun bukan setingkat. Hal tersebut Berdasarkan hasil angket dengan 301 informan yaitu:

Diagram 5.

Dominasi sekolah menengah atas (SMA) 1 Bantaeng sebagai kelas dominan

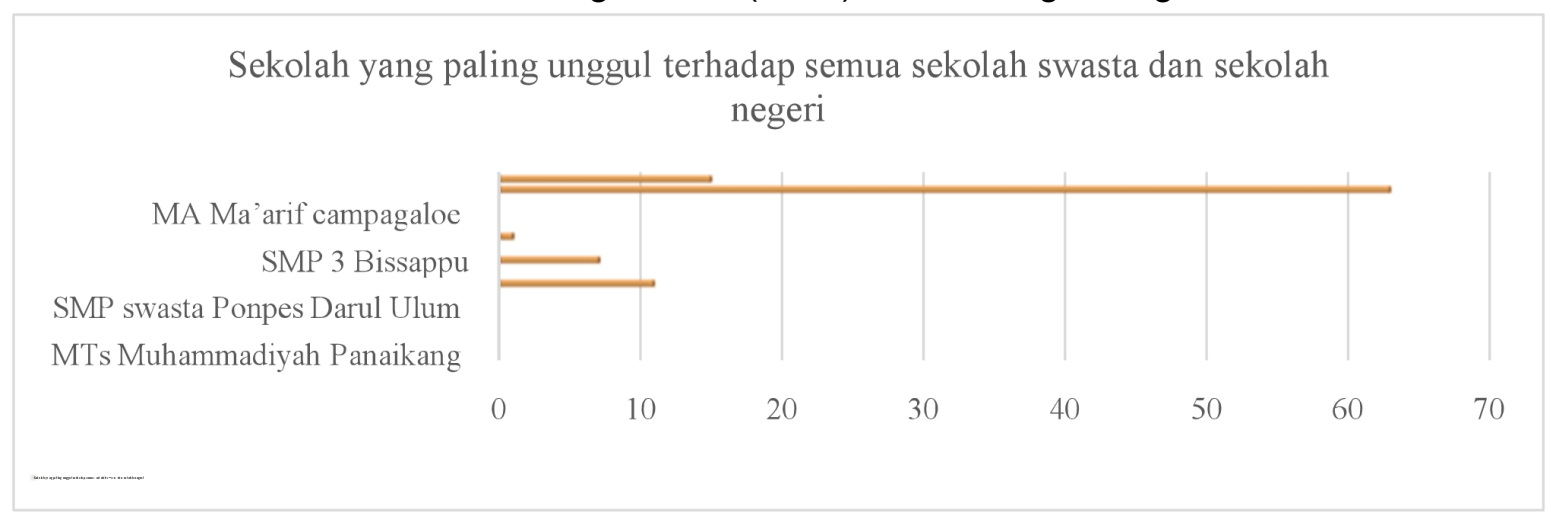


JURNAL ILMIAH MUQODDIMAH:

Jurnal Ilmu Sosial, Politik Dan Humaniora

E-ISSN : 2598-6236

http://jurnal.um-tapsel.ac.id/index.php/muqoddimah
Dominasi Sekolah Negeri Terhadap Sekolah Swasta Sebagai Penyebab Kekerasan Simbolik Terhadap Siswa Sekolah Swasta. (Suardi, Andi Agustang, Jumadi)

Hasil angket dari 301 responden terkait sekolah yang unggul terhadap sekolah swasta dan sekolah negeri, menempatkan sekolah SMA 1 Bantaeng sebagai sekolah yang paling unggul dibandingkan sekolah swasta dan sekolah negeri dengan 191 responden atau $63.45 \%$, SMA 2 Bantaeng dengan 48 atau $15.94 \%$,, SMP 1 Bissappu 35 responden atau $11.62 \%$, SMP 3 Bissappu 24 responden atau $7.97 \%$ dan MA Muhammadiyah Panaikang 3 atau $0.99 \%$, Responden, sedangkan sekolah yang lain tidak ada.Tipe dominasi dominasi kelas dominan sekolah negeri terhadap semua sekolah swasta dan sekolah negeri yang lain yang selevel yaitu:

Tabel 5 .

Dominasi s sekolah menengah atas (SMA) 1 Bantaeng sebagai kelas dominan

\begin{tabular}{llcccccc} 
No & Interval respon & Kategori & A & B & G & H & J \\
1 & $81-100$ & Sangat unggul & - & - & - & - & - \\
2 & $61-80$ & Unggul & 63.45 & - & - & - & - \\
3 & $41-60$ & Sedang-Sedang & - & - & - & - & - \\
4 & $21-40$ & Kurang Unggul & - & - & - & - & - \\
5 & $0-20$ & Tidak Unggul & - & 15.9 & 0.99 & 11.6 & 7.97 \\
& & & & 4 & & 2 & \\
\hline
\end{tabular}

Keterangan:

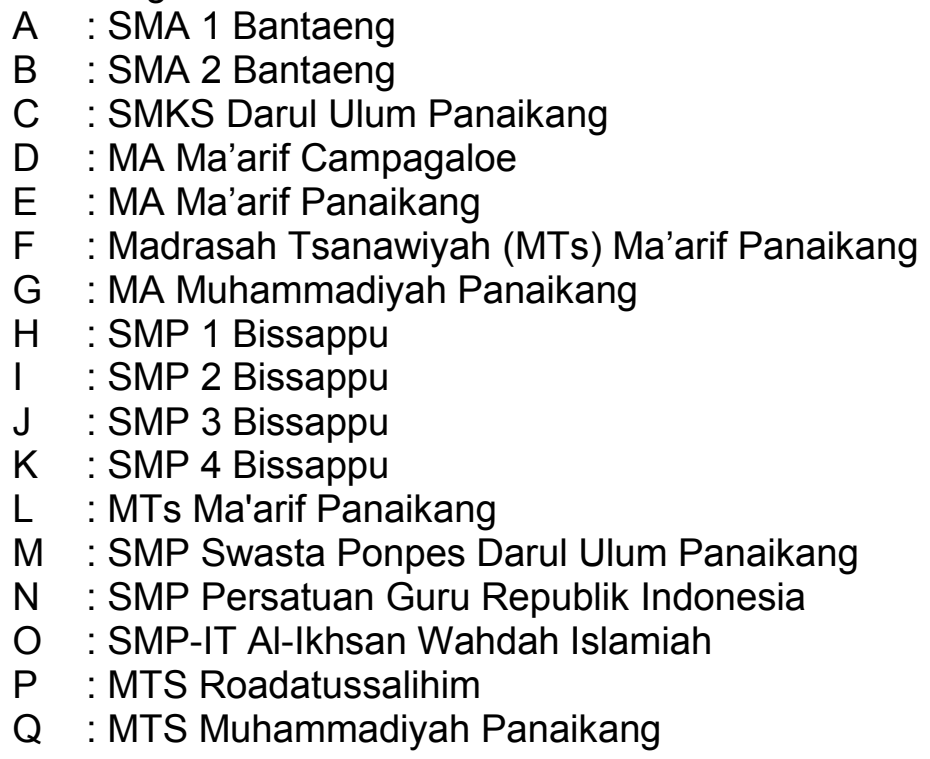

Berdasarkan tabel tersebut maka dominasi sekolah terhadap semua sekolah swasta maupun sekolah negeri setingkat dan tidak setingkat didominasi oleh SMA 1 Bantaeng yang memiliki nilai tertinggi pada kategori unggul, mendominasi sekolah yang lain seperti SMA 1 Bantaeng, SMP 1 Bissappu, SMP 3 Bissappu dan MA Muhammadiyah Panaikang yang berada pada kategori kurang unggul, termasuk sekolah yang lain yang tidak memiliki nilai. Keunggulan sekolah negeri terhadap sekolah swasta dapat dilihat pada diagram berikut: 
JURNAL ILMIAH MUQODDIMAH: Jurnal IImu Sosial, Politik Dan Humaniora E-ISSN : 2598-6236

http://jurnal.um-tapsel.ac.id/index.php/muqoddimah
Dominasi Sekolah Negeri Terhadap Sekolah Swasta Sebagai Penyebab Kekerasan Simbolik Terhadap Siswa Sekolah Swasta. (Suardi, Andi Agustang, Jumadi)

Diagram 6.

Dominasi sekolah negeri sebagai kelas dominan

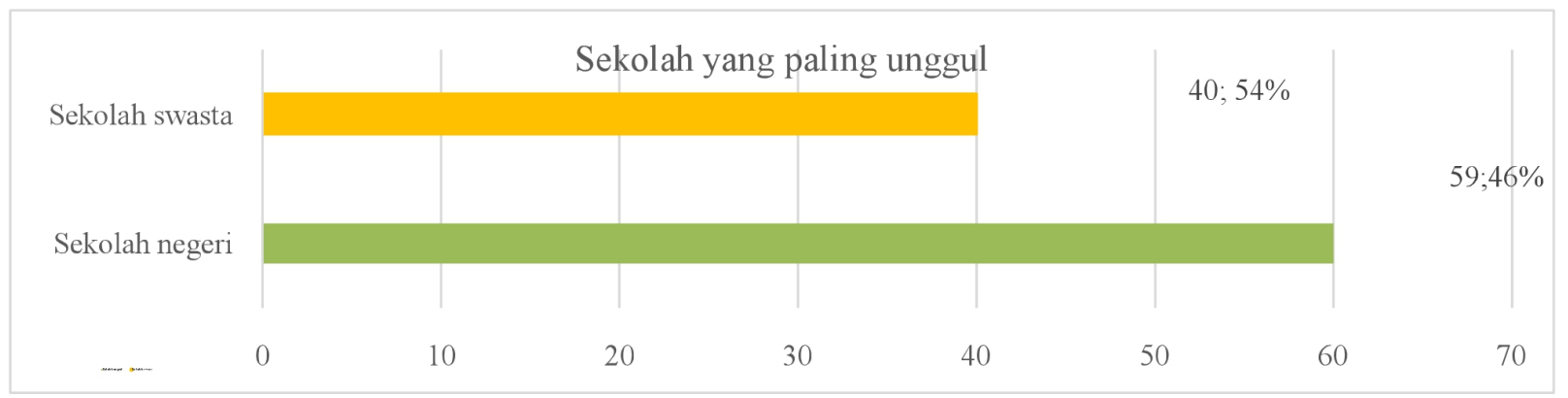

Hasil angket dari 301 responden terkait sekolah yang unggul di Kecamatan Bissappu dengan Kriteria sekolah swasta dan sekolah negeri secara umum, ada 179 responden atau $59.46 \%$ dari 301 responden yang memilih sekolah negeri lebih unggul dibandingkan sekolah swasta secara umum dan ada 120 orang responden atau $40.54 \%$ dari dari 303 responden yang memilih sekolah swasta lebih unggul dibandingkan sekolah negeri secara umum. Tipe dominasi sekolah negeri terhadap sekolah swasta yaitu:

Tabel 6.

Kategori dominasi sekolah negeri sebagai kelas dominan

\begin{tabular}{|c|c|c|c|c|}
\hline No & Interval respon & Kategori & $\begin{array}{c}\text { Sekolah } \\
\text { negeri }\end{array}$ & $\begin{array}{c}\text { Sekolah } \\
\text { swasta }\end{array}$ \\
\hline 1 & $81-100$ & Sangat unggul & - & - \\
\hline 2 & $61-80$ & Unggul & - & - \\
\hline 3 & $41-60$ & Sedang-Sedang & 59.46 & - \\
\hline 4 & $21-40$ & Kurang Unggul & - & 40.54 \\
\hline 5 & $0-20$ & Tidak Unggul & - & - \\
\hline
\end{tabular}

Berdasarkan tabel tersebut maka dominasi sekolah negeri masih unggul dibandingkan dengan sekolah swasta, sekolah negeri berada pada kategori sedang-sedang, sedangkan sekolah swasta yang hanya masuk kategori kurang unggul jika dibandingkan dengan sekolah negeri secara umum.

\section{Pembahasan}

Di Kecamatan Bissappu Kabupaten Bantaeng terdapat berbagai tipe dominasi sekolah, secara umum yaitu (a) Dominasi kelas dominan terhadap kelas popular dan kelas borjuasi yang selevel, (b) Dominasi kelas dominan terhadap kelas popular dan kelas borjuasi yang tidak selevel, (c) Dominasi kelas dominan terhadap kelas populer dan kelas borjuasi yang selabel dan (c) Dominasi kelas dominan terhadap kelas populer dan kelas borjuasi yang tidak selabel (Suardi, Agustang, \& Jumadi, 2020b).

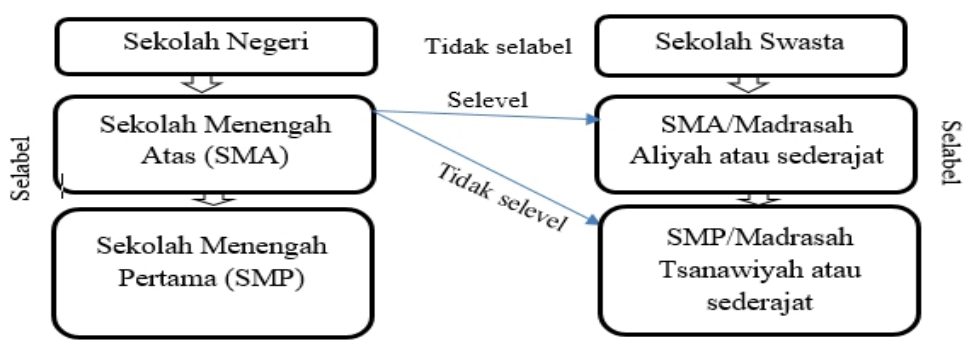

Gambar: Ilustrasi dominasi kelas dominan terhadap kelas borjuis dan kelas popular yang selabel dan selevel. 
JURNAL ILMIAH MUQODDIMAH: Jurnal IImu Sosial, Politik Dan Humaniora E-ISSN : 2598-6236

http://jurnal.um-tapsel.ac.id/index.php/muqoddimah
Dominasi Sekolah Negeri Terhadap Sekolah Swasta Sebagai Penyebab Kekerasan Simbolik Terhadap Siswa Sekolah Swasta. (Suardi, Andi Agustang, Jumadi)

Namun diantara semua tipe dominasi yang paling banyak adalah tipe dominasi kelas dominan terhadap kelas populer dan kelas borjuasi yang tidak selabel yaitu sekolah negeri sebagai kelas dominan sekolah swasta sebagai kelas populer dan kelas borjuasi yang berbeda status sekolah. Sekolah negeri secara umum sebagai kelas dominan dalam pertarungan dengan sekolah swasta pada suatu arena (feil) pendidikan di Kecamatan Bissappu (Suardi, Agustang, \& Jumadi, 2020b), untuk melakukan pemaksaan habitus yaitu dengan menjadikan sekolah negeri sebagai contoh dalam menciptakan kebiasaan belajar yang bagus dan pengelolaan praktik pendidikan yang terbaik. Pemaksaan habitus adalah bagian dari kekerasan simbolik (Suardi, Agustang, \& Jumadi, 2020a). Dominasi yang terjadi secara khusus terdiri dari tujuh tipe dominasi yaitu berdasarkan dominasi kualitas dan dominasi kuantitas, yaitu (1) Tipe dominasi kelas dominan sekolah menengah atas negeri terhadap sekolah negeri setingkat yang lain menjadikan sekolah menengah atas (SMA) 1 Bantaeng sebagai kelas dominan terhadap sekolah negeri setingkat, (2) Tipe kelas dominan sekolah menengah atas atau sederajat swasta terhadap sekolah swasta yang lain setingkat menjadikan sekolah MA Muhammadiyah Panaikang sebagai kelas dominan terhadap sekolah swasta setingkat, (3) Tipe dominasi kelas dominan sekolah menengah pertama negeri terhadap sekolah negeri setingkat yang lain menjadikan sekolah menengah pertama SMP 1 Bissappu sebagai kelas dominan terhadap sekolah swasta setingkat, (4) Tipe kelas dominan sekolah sekolah menengah pertama atau sederajat swasta terhadap sekolah swasta yang lain setingkat menjadikan sekolah MTs Muhammadiyah Panaikang sebagai kelas dominan terhadap sekolah swasta setingkat, (5) Tipe dominasi kelas dominan sekolah negeri terhadap semua sekolah swasta dan sekolah negeri yang lain menjadikan sekolah menengah atas (SMA) 1 Bantaeng sebagai kelas dominan terhadap semua sekolah swasta dan negeri baik setingkat maupun bukan setingkat. Namun secara umum dominasi antara kelas sekolah negeri dan kelas sekolah swasta tetap menempatkan sekolah negeri sebagai kelas dominan dan menjadikan sekolah swasta sebagai kelas populer dan borjuasi yang didominasi.

Dominasi digunakan untuk menjelaskan hubungan kekuatan antar pribadi atau kelompok atau antar bentuk kekuasan seperti halnya kekuasaan dalam praktik pendidikan (Bourdieu, 1993). Dominasi menjadi dasar setiap kelas dominan melakukan kekerasan terhadap kelas yang didominasi yaitu kelas populer dan kelas borjuasi. Karena hakikatnya dominasi sangat erat kaitannya dengan kekerasan simbolik, karena salah satu tujuan melakukan kekerasan simbolik memiliki tujuan untuk melakukan kontrol dan dominasi terhadap orang lain (Grimaldi et al., 2015), termasuk control dan kekuasaan terhadap siswa sekolah swasta, seperti yang dikemukakan Bourdieu, kekerasan berada dalam lingkup kekuasaan, sehingga kekerasan terhadap siswa merupakan pangkal atau hasil sebuah praktik kekuasaan. Ketika ada sekolah sebagai kelas yang mendominasi sekolah yang lain, maka di dalam proses tersebut akan menghasilkan sebuah kekerasan. Untuk menjalankan aksi dominasi melalui kekerasan, kelas dominan selalu berupaya agar aksinya tidak mudah dikenali. Mekanisme kekerasan yang dilakukan kelas dominan dilakukan secara perlahan namun pasti, sehingga kelas bawah tidak sadar bahwa dirinya menjadi objek kekerasan. Dengan demikian, kelas dominan memilik kekuasaan yang digunakan untuk mendominasi kelas yang tidak beruntung, kelas tertindas. Mekanisme kekerasan seperti inilah yang disebut sebagai kekerasan simbolik (Suardi, Agustang, \& Jumadi, 2020b). Siswa sekolah swasta dapat didiskriminasikan atau ditindas karena perebutan kekuasaan antara sekolah swasta dengan sekolah negeri (Suardi, Agustang, \& Jumadi, 2020b). Diskriminasi adalah masalah sosial yang harus diatasi (Nursalam \& Suardi, 2016).

\section{SIMPULAN DAN SARAN}

Dominasi sekolah negeri menjadi salah satu faktor penyebab kekerasan simbolik terhadap siswa sekolah swasta. Dominasi sekolah negeri terhadap sekolah swasta terbagi menjadi beberapa varian yaitu (1) Tipe dominasi kelas dominan sekolah menengah atas negeri terhadap 
JURNAL ILMIAH MUQODDIMAH: Jurnal IImu Sosial, Politik Dan Humaniora E-ISSN : 2598-6236

http://jurnal.um-tapsel.ac.id/index.php/muqoddimah
Dominasi Sekolah Negeri Terhadap Sekolah Swasta Sebagai Penyebab Kekerasan Simbolik Terhadap Siswa Sekolah Swasta. (Suardi, Andi Agustang, Jumadi)

sekolah negeri setingkat yang lain menjadikan sekolah menengah atas (SMA) 1 Bantaeng sebagai kelas dominan terhadap sekolah negeri setingkat, (2) Tipe kelas dominan sekolah menengah atas atau sederajat swasta terhadap sekolah swasta yang lain setingkat menjadikan sekolah MA Muhammadiyah Panaikang sebagai kelas dominan terhadap sekolah swasta setingkat, (3) Tipe dominasi kelas dominan sekolah menengah pertama negeri terhadap sekolah negeri setingkat yang lain menjadikan sekolah menengah pertama SMP 1 Bissappu sebagai kelas dominan terhadap sekolah swasta setingkat, (4) Tipe kelas dominan sekolah sekolah menengah pertama atau sederajat swasta terhadap sekolah swasta yang lain setingkat menjadikan sekolah MTs Muhammadiyah Panaikang sebagai kelas dominan terhadap sekolah swasta setingkat, (5) Tipe dominasi kelas dominan sekolah negeri terhadap semua sekolah swasta dan sekolah negeri yang lain menjadikan sekolah menengah atas (SMA) 1 Bantaeng sebagai kelas dominan terhadap semua sekolah swasta dan negeri baik setingkat maupun bukan setingkat.

\section{UCAPAN TERIMAKASIH}

Ucapan terimakasih Kepada Pimpinan Universitas Muhammadiyah Makassar dan Pimpinan Universitas Negeri Makassar yang telah memberikan dukungan dalam penyelesaian hasil penelitian dan publikasi hasil penelitian.

\section{DAFTAR PUSTAKA}

Arifin, J., \& Suardi, S. (2017). Stigmatisasi dan Perilaku Diskriminatif pada Perempuan Bertato. Equilibrium: Jurnal Pendidikan, 3(1), 1-9. https://doi.org/10.26618/equilibrium.v3i1.507

Bourdieu, F. (1993). The Field of Cultural Production (R. Johnson (ed.)). Columbia University Press.

http://en.bookfi.net/s/?q=Bourdieu\%2C+Fierre.+\%281993\%29+The+Field+of+Cultural+Pro duction $\% 3 A+E s s a y s+o n+A r t+a n d+$ Literature+Colombia+University+Press.\& $t=0$

Creswell, J. W. (2017). Research Design: Qualitative, Quantitative, and Mixed Methods Approaches. Sage publication. http://en.bookfi.net/book/1119284

Grimaldi, E., Serpieri, R., \& Spanò, E. (2015). Positionality, symbolic violence and reflexivity: Researching the educational strategies of marginalised groups. Researching Marginalized Groups, 134-138.

Kanji, H., Nursalam, N., Nawir, M., \& Suardi, S. (2019a). Evaluasi Integrasi Pendidikan Karakter dalam Pembelajaran IImu Pengetahuan Sosial di Sekolah Dasar. JED (Jurnal Etika Demokrasi), 4(2), 56-63. https://doi.org/10.26618/jed.v4i2.2386

Kanji, H., Nursalam, Nawir, M., \& Suardi. (2019b). Model Integrasi Pendidikan Karakter dalam Pembelajaran IImu Pengetahun Sosial di Sekolah Dasar. Jurnal Pendidikan Dasar Perkhasa , 5(2), 104-115. https://doi.org/10.31932/jpdp.v5i2.458

Kanji, H., Nursalam, Nawir, M., \& Suardi. (2020). Supporting and Inhibiting Factors of Character Education in Learning Social Studies at Primary Schools. JED (Journal of Etika Demokrasi), 5(1), 1-14. https://doi.org/10.26618/JED.V5I1.2966

Laksana, B. W. (2012). Pelanggengan Kekuasaan dalam Novel Kubah di Atas Pasir Karya Zhaenal Fanani ( Kajian Kekerasan Simbolik Pierre Bourdieu ) Bramantika Wahyu Laksana Abstrak. Bapala, 7(1), 1-13. https://jurnalmahasiswa.unesa.ac.id/index.php/bapala/article/view/33221

Nursalam, Manda, D., \& Suardi. (2018). Sexual Abuse (Study of Child Sexual Abuse in Poleang District Bombana Regency). Palarch's Journal of Archaralogy of Egypt/Egyptogy, 17(2), 232-240. http://www.palarch.nl/index.php/jae/article/view/210/155

Nursalam, Nawir, M., Suardi, \& Kanji, H. (2020). MODEL PENDIDIKAN KARAKTER PADA MATA PELAJARAN ILMU PENGETAHUAN SOSIAL DI SEKOLAH DASAR (Vol. 1). CV. $\mathrm{AA}$. RIZKY. https://books.google.co.id/books?hl=id\&lr=\&id=8tUKEAAAQBAJ\&oi=fnd\&pg=PA63\&dq=buk 
JURNAL ILMIAH MUQODDIMAH: Jurnal IImu Sosial, Politik Dan Humaniora E-ISSN : 2598-6236

http://jurnal.um-tapsel.ac.id/index.php/muqoddimah
Dominasi Sekolah Negeri Terhadap Sekolah Swasta Sebagai Penyebab Kekerasan Simbolik Terhadap Siswa Sekolah Swasta. (Suardi, Andi Agustang, Jumadi)

$\mathrm{u}+$ suardi+nursalam+pendidikan+karakter\&ots $=1 \mathrm{~A}--$

g2fQs4\&sig=zVhj4kYePdGJVf09G4I9nxFs-H4\&redir_esc=y\#v=onepage\&q=buku suardi nursalam pendidikan karakter\&f=false

Nursalam, \& Suardi. (2016). Sosiologi Pengantar Masyarakat Indonesia. Yogyakarta: Writing Revolution.

Nursalam, S. Syarufuddin.(2016). Teori Sosiologi Klasik, Modern, Posmodern, Saintifik, Hermeneutik, Kritis, Evaluatif, dan Integratif. Yogyakarta: Writing Revolution.

Suardi. (2018). SOSIOLOGI KOMUNITAS MENYIMPANG (Vol. 1). Writing Revolution. https://books.google.co.id/books?id=F9kKEAAAQBAJ\&printsec=frontcover\&dq=SOSIOLO GI+KOMUNITAS+MENYIMPANG\&hl=id\&sa=X\&ved=2ahUKEwinvPjNy7DtAhUIX30KHbN8 Cc0Q6AEwAHoECAAQAg\#v=onepage \&q=SOSIOLOGI MENYIMPANG\&f=false

KOMUNITAS

Suardi, Agustang, A., \& Jumadi. (2020a). Symbolic Violence Towards Students in the Context of the Existence of the Stereotypical Frames of Lecturers and Students in the Higher Education System in Indonesia. Palarch's Journal of Archaralogy of Egypt/Egyptogy 17(2),17(2), 249-258. http://www.palarch.nl/index.php/jae/article/view/210/155

Suardi, Agustang, A., \& Jumadi. (2020b). THE SYMBOLIC VIOLENCE TOWARDS PRIVATE SCHOOL STUDENTS THROUGH THE FRAME STEREOTYPE IN BANTAENG DISTRICT OF INDONESIA. The International Conference on Innovations in Social Sciences and Education, 578-588.

Suardi, Agustang, A., \& Sahabuddin, J. (2020). MODEL KOLABORASI SOSIAL PENDIDIKAN KARAKTER DI SEKOLAH SWASTA KECAMATAN BISSAPPU KABUPATEN BANTAENG. PROSIDING SEMINAR DAN DISKUSI PENDIDIKAN DASAR, 1-11. http://journal.unj.ac.id/unj/index.php/psdpd/article/view/17769

Suardi, Nursalam, \& Kanji, H. (2020). PENGUATAN PENDIDIKAN KARAKTER: BERBASIS INTEGRATIF MORAL DI PERGURUAN TINGGI (Vol. 1). CV. AA. RIZKY. https://books.google.co.id/books?hl=id\&lr=\&id=DOADEAAAQBAJ\&oi=fnd\&pg=PA1\&dq=bu $\mathrm{ku}+$ suardi+nursalam+pendidikan+karakter\&ots $=\mathrm{aL} 1 \mathrm{dBe}$ - $U$ e3\&sig=oMu7hsupROIXcDnclso 8Ldgl_Oc\&redir_esc=y $\# \mathrm{v}=$ onepage \&q=buku suardi nursalam pendidikan karakter\&f=false

Suardi, S., Herdiansyah, H., Ramlan, H., \& Mutiara, I. A. (2019). Implementasi Pendidikan Karakter Melalui Mata Pelajaran Pendidikan Kewarganegaraan di SMA Jaya Negara Makassar. JED (Jurnal Etika Demokrasi), 4(1), 22-29. https://doi.org/10.26618/jed.v4i1.1983

Suardi, S., Megawati, M., \& Kanji, H. (2018). Pendidikan Karakter di Sekolah (Studi Penyimpangan Siswa di Mts Muhammadiyah Tallo). JED (Jurnal Etika Demokrasi), 3(1), 75-84. https://doi.org/10.26618/jed.v3i1.1979

Suardi, \& Syarifuddin. (2018). Penerapan Model Pembelajaran Saintifik Approacd Berbasis Media Pembelajaran Kearifan Lokal pada Mata Kuliah Dasar-Dasar Sosiologi dalam Membangun Karakter dan Meningkatkan Hasil Belajar Mahasiswa Pendidikan Sosiologi Universitas Muhammadiyah Makassar. JED (Jurnal Etika Demokrasi), 3(2), 75-85. https://doi.org/10.26618/jed.v3i2.1627 